\title{
Influence of the Soil Solarization Management and Fertilizer on Soil Temperature under Different Soil Tillage Systems
}

\author{
Ahmed Abed Gatea Al-Shammary ${ }^{1}$, Jamal Naser Abedalrahman Al-Sadoon ${ }^{1} \&$ Nabil Raheem Lahmod ${ }^{2}$ \\ ${ }^{1}$ Soil Science and Water Resources Departments, College of Agriculture, University of Wasit, Kut, Iraq \\ ${ }^{2}$ Field Crop Department, College of Agriculture, University of Wasit, Kut, Iraq \\ Correspondence: Ahmed Abed Gatea Al-Shammary, Soil Science and Water Resources Departments, College of \\ Agriculture, University of Wasit, Kut, Iraq. Tel: 964-780-187-0847. E-mail: ahmedabd192000@yahoo.com
}

\author{
Received: November 17, 2015 Accepted: December 19, 2015 Online Published: January 15, 2016 \\ doi:10.5539/jas.v8n2p98 \\ URL: http://dx.doi.org/10.5539/jas.v8n2p98
}

\begin{abstract}
The soil tillage system can notably influence soil solarization system under dry land farming in semiarid areas. Field experiments were conducted from $6 / 6 / 2013$ to $1 / 9 / 2013$, to evaluate the effects of soil tillage system, soil solarization system and fertilizer type on soil temperature at three depths as well as influence at gap between the mulch and soil surface. The experiment included three experimental factors. The first factor, soil tillage systems (moldboard plowing followed by spring disking $\{\mathrm{MP}\}$, Rotary plough $\{\mathrm{RP}\}$ ), the second factor represent the soil mulching systems in three levels (transparent mulch, black mulch and without mulch \{control\}), the third factor includes three fertilizers types (compose fertilizer; in compose fertilizer and chemical fertilizer). The results showed that the experimental factors effects on soil temperature, when used soil tillage system (MP), the higher soil temperature recorded at $10 \mathrm{~cm}$ depth, its value $70{ }^{\circ} \mathrm{C}$ ( time $11 \mathrm{am}$ ) when mean solar radiation $1146 \mathrm{w} / \mathrm{m}^{2}$ in soil transparent mulching system and chemical fertilizer, as well as for treatment soil black mulch and compose fertilizer, but the lower soil temperature recorded at $30 \mathrm{~cm}$ depth, its value $35.8^{\circ} \mathrm{C}$ (time $1 \mathrm{pm}$ ) when mean solar radiation $1147 \mathrm{w} / \mathrm{m}^{2}$ in soil transparent mulch and chemical fertilizer treatment. The highest soil temperature recorded at $10 \mathrm{~cm}$ depth, when used soil tillage system (RP), its value $78.3{ }^{\circ} \mathrm{C}$ (time 11 am) when mean solar radiation $1125 \mathrm{w} / \mathrm{m}^{2}$ in soil black mulch and chemical fertilizer, but the low soil temperature recorded at $30 \mathrm{~cm}$ depth, its value $41{ }^{\circ} \mathrm{C}$ (time $3 \mathrm{pm}$ ) when mean solar radiation $900 \mathrm{w} / \mathrm{m}^{2}$ in soil transparent mulch and compose fertilizer treatment. Moreover, the results showed the maximum temperature at gap between the mulch and the soil surface occurs at noon. Addition the obtained results demonstrated that all soil mulching system raised soil temperature substantially compared with without mulched.
\end{abstract}

Keyword: soil tillage system, soil mulch systems, soil temperature, solar radiation

\section{Introduction}

Soil temperature varies with time and space, as well as with land use systems and gas emissions and affects also the global change. Thermal properties are of main importance for the determination of rates and directions of soil physical, chemical and biological processes as well as for energy and mass exchange with the atmosphere. The temperature governs also evaporation, aeration, and biological processes, such as the uptake of nutrients and water by the roots, the decomposition of organic matter by microbes, the germination of seeds and seedling emergence. Thus, growth strongly depends on the temperature regime. Soil temperature shows a pronounced fluctuation with time and soil depth. These changes are propagated into the soil profile depending on the heat capacity, thermal diffusivity and heat conductivity.

Tillage has a strong influence on soil temperature. Plough changes the structure of the upper part of the soil and makes its structure looser and less continuous than the deeper parts. Soil temperature was highest in conventional (moldboard) tillage comparatively with three conservation tillage systems, chisel, till-plant, and no till (Johnson \& Lowery, 1985).

Physical, chemical, and biological processes which occur in soils are influenced by soil temperature. The rate of some processes increases by more than double for each $10{ }^{\circ} \mathrm{C}$ increase in temperature. Physical processes such as water movement and soil drying can also be strongly influenced by temperature (Hillel, 1998; Kowalik, 2004). Soil temperature should change with time because of solar-radiation changes on both a diurnal and yearly scale 
and because of continuously changing water contents (Scharringa, 1976).

The raise of temperature of solarized soil during the daytime is due to a decrease in sensible and latent heat fluxes, and there by it increases the amount of heat available for soil heating (Avissar et al., 1986; Liakatas et al., 1986).

The soil parameters, which allow information about the soil thermal regime, include the specific heat capacity, thermal conductivity, and thermal diffusivity. These parameters are strongly affected by the bulk density and water content. Internal sources and sinks of heat also play an important role in the soil thermal regime (Campbell, 1985; de Vries, 1996; Bachmann, 1997).

Sarkar et al. (2007) showed soil management regimes could change the characteristics of the soil surface, and hence influence the soil thermal properties. Several investigators have reported that the soil thermal regime under mulching is different from that of bare soil.

Mulches have been known to increase the soil temperature since the sun's energy passes through the mulch and heats the air and soil beneath the mulch directly and then the heat is trapped by the "greenhouse effect" (Hu et al., 1995; Ramakrishna et al., 2006). The soil temperature under plastic mulch depends on the thermal properties (reflectivity, absorbitivity or conductivity) of a particular material in relation to incoming solar radiation (Schales \& Sheldrake, 1963). The efficiency with which black mulch increases soil temperature can be improved by optimizing the condition for transferring heat from the mulch to the soil (Aniekwe et al., 2004). The aim of this work was to study the influence of soil tillage system, soil mulch system and fertilizer type on the soil temperature at three soil depths.

\section{Material and Methods}

\subsection{Location}

The research field is located in the College of Agriculture field, University of Wasit, Kut, Iraq. The experimental field is situated with coordinate's longitude $45.846774 \mathrm{E}$, latitude $32.498392 \mathrm{~N}$ in a slightly undulating area.

\subsection{Climate}

The climate in Kut city Iraq has a hot, dry climate characterized by long, hot, dry summer and short, cool winter. The climate is influenced by Iraq's location between the subtropical aridity of the Arabian Desert areas and the subtropical humidity of the Arabian Gulf.

Most of the areas, in summer, are warm with long sunshine hours, the temperatures can be very hot, on some days it can be up to $45^{\circ} \mathrm{C}$ or more.

\subsection{Experiments Design \& Procedures}

Cleaning and disposal the field experiment from grass and plants, after soil sample take proposer calculation some soil properties as showed Table 1 . The experiment included the studying of the effect of three experimental factors. The first, two management systems were (moldboard plowing followed by spring disking $\{\mathrm{MP}\}$, Rotary plough $\{R P\}$ ). The second factor represents the soil mulching systems in three levels (transparent mulch, black mulch and without mulch \{control\}). The third factor includes three fertilizer type (compose fertilizer; in compose fertilizer at a rate of $32 \mathrm{Mg} \mathrm{ha}^{-1}$ and chemical fertilizer at a rate of $250 \mathrm{~kg} \mathrm{ha}^{-1}$ as di ammonium phosphate (DAP)). An area was treated $\left(2 \mathrm{~m}^{2}\right)$ that it is out of the total area $\left(108 \mathrm{~m}^{2}\right)$. Experiment included (18 treat $\times 3$ replicates) total treatment 54 experimental units.

Use of farm tractor New Holland TC 54, distribution of fertilizer treatments by field of experience design then mixed the fertilizer with soil mixing manually. Installation of Thermocouple type (k) was used in the experimental units for the purpose of measuring soil temperature for three soil depths $(10,20,30 \mathrm{~cm})$. Before any step, irrigation of field was done to the level of field capacity. Mulch of experimental units by plastic sheets (transparent mulch thicknesses $0.5 \mathrm{~mm}$ width $6 \mathrm{~m}$, black mulch thicknesses $0.5 \mathrm{~mm}$ width $1 \mathrm{~m}$, without mulch) used polyethylene film of various Iranin's made for the purpose of soil solarization. Covering the mulched experimental was done from the date of $6 / 6 / 2013$ to $1 / 9 / 2013$. Measurement the soil temperature was done at three soil depths, ambient temperature, temperature between (mulch and soil surface) for every hour by Digital thermometer MT-4011 Two numbers were achieved. Measurements of solar radiations every hour by solar power meter TM-207 were done as well. 
Table 1. Some physical and chemical properties of the investigated soil

\begin{tabular}{|c|c|c|c|c|c|c|c|c|c|c|c|c|c|c|}
\hline \multirow{2}{*}{$\begin{array}{l}\text { Soil depth } \\
(\mathrm{cm})\end{array}$} & \multirow{2}{*}{$\begin{array}{l}\mathrm{EC} \\
\left(\mathrm{dsm}^{-1}\right)\end{array}$} & \multicolumn{8}{|c|}{$\mathrm{C} \mathrm{mol} / \mathrm{L}$} & \multirow{2}{*}{$\begin{array}{l}\mathrm{Pb} \\
\left(\mathrm{mg} / \mathrm{m}^{3}\right)\end{array}$} & \multicolumn{3}{|c|}{ Particle size distribution (\%) } & \multirow{2}{*}{ Texture } \\
\hline & & $\mathrm{CO}_{3}^{-2}$ & $\mathrm{HCO}_{3}^{-1}$ & $\mathrm{Cl}^{-1}$ & $\mathrm{SO}_{4}^{-2}$ & $\mathrm{Ca}^{+2}$ & $\mathrm{Mg}^{+2}$ & $\mathrm{Na}^{+}$ & $\mathrm{K}^{+}$ & & Clay & Silt & Sand & \\
\hline $0-10$ & 2.06 & 0.00 & 7 & 13 & 1.4 & 14.4 & 4 & 3.85 & 0.717 & 1.21 & 16 & 56 & 28 & \\
\hline $10-20$ & 1.70 & 0.00 & 9 & 8 & 1.1 & 7.2 & 8 & 2.9 & 0.651 & 1.24 & 14 & 58 & 28 & Loam \\
\hline $20-30$ & 1.34 & 0.00 & 10 & 3 & 1.0 & 8.3 & 2 & 2.6 & 0.648 & 1.29 & 18 & 51 & 31 & \\
\hline
\end{tabular}

\section{Results and Discussion}

\subsection{The Influence Soil Tillage System (MP), Soil Mulch System and Fertilizer Type on Soil Temperature with Three Soil Depths}

Figure 1 showed the diurnal variation of soil temperature, air temperature, solar radiation for a dry (23nd June 2013) day under different soil mulch systems and fertilizer used tillage system (MP), Large diurnal variations are significant up to $30 \mathrm{~cm}$ soil depth.

Mean temperature at gap between mulch and soil surface ranged from a high of $81{ }^{\circ} \mathrm{C}$ (time $11 \mathrm{am}$ ) when solar radiation at $1147 \mathrm{w} / \mathrm{m}^{2}$ in soil black mulching system and chemical fertilizer (Figure 1E) to a lower of $43.1{ }^{\circ} \mathrm{C}$ (time $3 \mathrm{pm}$ ) when solar radiation $845 \mathrm{w} / \mathrm{m}^{2}$ in transparent mulch \& compose fertilizer with Figure 1B. While at $10 \mathrm{~cm}$ depth, the mean soil temperature ranged from as high as $70{ }^{\circ} \mathrm{C}$ (time $11 \mathrm{am}$ ) when mean solar radiation $1146 \mathrm{w} / \mathrm{m}^{2}$ in soil transparent mulch \& chemical fertilizers; as well as for treatment in soil black mulch \& compose fertilizer (see Figure 1C and Figure 1F respectively), to a lower soil temperature of $40{ }^{\circ} \mathrm{C}(3 \mathrm{pm})$ when solar radiation $900 \mathrm{w} / \mathrm{m}^{2}$ in soil transparent mulch \& chemical fertilizers with Figure 1C.

Furthermore, the mean soil temperature at $20 \mathrm{~cm}$ soil depth ranged from a high of $68{ }^{\circ} \mathrm{C}(11 \mathrm{am})$ when solar radiation $1142 \mathrm{w} / \mathrm{m}^{2}$ in soil black mulch \& compose fertilizer Figure $1 \mathrm{~F}$, to lower soil temperature of $38{ }^{\circ} \mathrm{C}(2$ $\mathrm{pm}$ ) when solar radiation $1000 \mathrm{w} / \mathrm{m}^{2}$ in soil transparent mulch \& chemical fertilizers Figure 1C. While at $30 \mathrm{~cm}$ depth, the mean soil temperature ranged from high of $68.6{ }^{\circ} \mathrm{C}(11 \mathrm{am})$ when solar radiation $1142 \mathrm{w} / \mathrm{m}^{2}$ in soil black mulch \& chemical fertilizer Figure 1E, to a lower soil temperature $35.8^{\circ} \mathrm{C}(1 \mathrm{pm})$. When solar radiation will be $1147 \mathrm{w} / \mathrm{m}^{2}$ in transparent mulch \& chemical fertilizers Figure 1C.

Increasing in soil temperatures was observed in the soil mulched plots compared with the without mulch plots which also agreed with former findings (Fabrizzi et al., 2005; Olasantan, 1999; Park et al., 1996).

Figure 1 and Table 2 represent the influence of soil tillage system (MP), soil mulch system and fertilizer type on soil temperature at three soil depth.

The results showed difference between the three experimental factors on soil temperature. The black mulch absorbs most up, visible and infrared wavelengths of incoming solar radiation and re-radiates absorbed energy in the form of thermal radiation or long wavelength infrared radiation. Where the thermal conductivity of the soil is high, relative to that of air, much of the energy absorbed by plastic can be transferred to the soil by conduction if contact between soil surface and plastic mulch is good.

Transparent plastic mulch absorbs little solar radiation. However, it transmits 85\%-95\%, with relative transmissions depending on the thickness and degree of opacity of the polyethylene (Lamont, 1999). For this reasons the soil black mulching had soil temperature higher than soil transparent mulch and soil without mulch, These result agreed with the result which was obtained by Lamont (1999), Angima (2009), and Anikwe (2007). The results indicated that temperature of solarized soil was on the average $5.4,4.5$ and $4{ }^{\circ} \mathrm{C}$ higher than soil without mulch at 10,20,30 depth respectively. Results indicated that the average temperature in both soil solarized and soil without mulch decreased when soil depth increased. These results agreed with the results which were obtained by (Streck et al., 1994).

From Table 2 showed the lower Coefficient of Variation 7.7 occurred at 11 am in the means soil temperature for gap between mulch and soil surface for $20 \mathrm{~cm}$ depth, the largest coefficient of variation recorded 17.1 at 9 am for the means soil temperature $30 \mathrm{~cm}$ depth when used tillage system (MP) was used. 

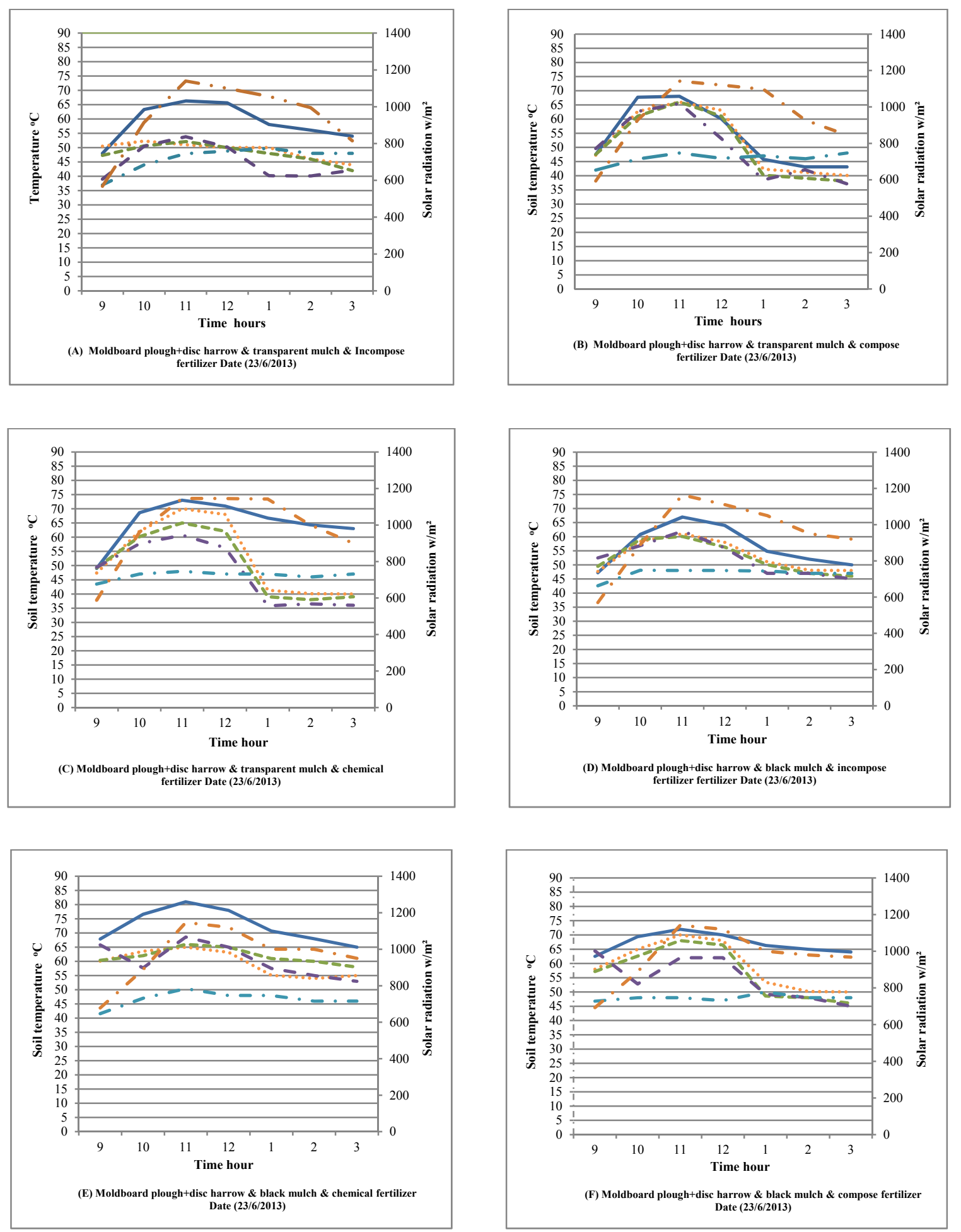

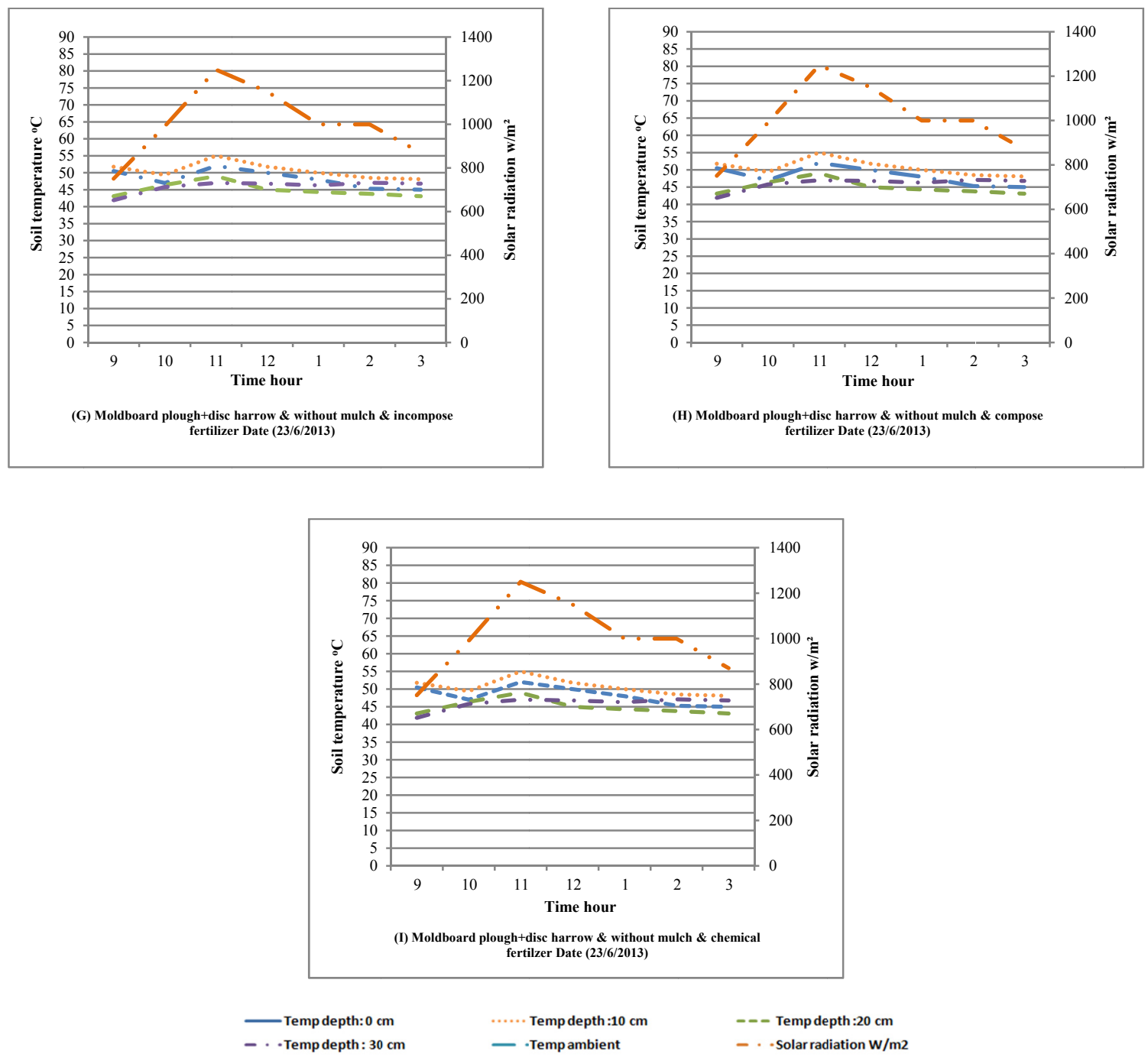

Figure 1. Relationship between soil temperature through three soil depths, ambient, solar radiation in time using tillage system (MP), soil solarazation system difference and fertilizer types

\subsection{The Influence Soil Tillage System (RP), Soil Mulch System and Fertilizer Type on Soil Temperature with three Soil Depth}

Figure 2 shows the average temperature at gap between mulch and soil surface, soil temperature, ambient and solar radiation for 24 June. The temperature of gap between mulch and soil surface of soil black mulching and compose fertilizer type treatment ranged from higher $83.2^{\circ} \mathrm{C}$ at 11 am when solar radiation $1130 \mathrm{w} / \mathrm{m}^{2}$ (Figure 2C), to a lower temperature $51{ }^{\circ} \mathrm{C}$ at $3 \mathrm{pm}$ when (solar radiation $=900 \mathrm{w} / \mathrm{m}^{2}$ ) of the soil transparent mulching and compose fertilizer (Figure 2D). Also the results showed the mean soil temperature of soil black mulch \& Chemical fertilizer treatment at $10 \mathrm{~cm}$ soil depth was ranged from high $78.3{ }^{\circ} \mathrm{C}$ at 11 am when solar radiation $1125 \mathrm{w} / \mathrm{m}^{2}$ (Figure 2B), to a lower soil temperature at $10 \mathrm{~cm} 41.4^{\circ} \mathrm{C}$ at $9 \mathrm{am}$, solar radiation $921 \mathrm{w} / \mathrm{m}^{2}$ when soil without mulching \& incompose fertilizer (Figure 2I). The high mean soil temperature at the soil depth $20 \mathrm{~cm}$ $76.8^{\circ} \mathrm{C}$ at $11 \mathrm{am}$, solar radiation $1125 \mathrm{w} / \mathrm{m}^{2}$ under soil black mulching and chemical fertilizer treatment (Figure 2B), lower soil temperature $41.5^{\circ} \mathrm{C}$ at $3 \mathrm{pm}$, solar radiation $900 \mathrm{w} / \mathrm{m}^{2}$ under soil transparent mulch \& compose fertilizer (Figure 2D). Additionally,observed high soil temperatures $68.3{ }^{\circ} \mathrm{C}$ at $11 \mathrm{am}$, solar radiation $1125 \mathrm{w} / \mathrm{m}^{2}$ for soil depth $30 \mathrm{~cm}$ under soil black mulching and chemical fertilizer treatment (Figure 2B), lower soil temperature $41{ }^{\circ} \mathrm{C}$ at $3 \mathrm{pm}$, solar radiation $900 \mathrm{w} / \mathrm{m}^{2}$ under soil transparent mulch \& compose fertilizer (Figure 2D).

Figure 2 and Table 3 represent the influence of soil tillage system (RP), soil mulch system and fertilizer type on soil temperature at three soil depths. The results show that the soil temperature of rotary cultivator plow and 
black mulch and compose fertilizer was higher than soil transparent mulch and compose fertilizer at gap between mulch and soil surface because of differences between the two mulch systems in thermal properties. The results indicated that temperature of solarized soil was, on the average $9.4,9.2$ and $9.2{ }^{\circ} \mathrm{C}$ higher than soil without mulch at 10, 20 and $30 \mathrm{~cm}$ depth respectively. These results agreed with the results which were obtained by (Anikwe et al., 2007). Also the results indicated that average temperature in both soil solarized and soil without mulch decreased when soil depth increased. These results agreed with the results which were obtained by (Streck et al, 1994). The results indicated that the high temperature observed at soil black mulch and chemical fertilizer treatment, but the low temperature observed at soil transparent mulch and compose, in compose fertilizer treatments, the reasons of this differences were due to the soil temperature under plastic mulch which depended on the thermal properties (reflectivity, absorbtitivity or conductivity) of a particular material in relation to incoming solar radiation (Schales \& Sheldrake, 1963). The soil temperatures were highest in rotary plow comparatively with moldboard plow because of the formation of rough soil surface at moldboard, consequently an air space was created between the plastic mulch and the soil. However, the rotary plow formed smooth soil surface, thus the soil heat transferred by conduction in tillage system (rotary plow) too much than tillage system (moldboard).

Table 3 showed the lower coefficient of variation obtained 2.3 at 9 am in the temperature at gap between mulch and soil surface, the largest coefficient of variation recorded 15.4 at 9 am for the means soil temperature at 10 $\mathrm{cm}$ depth used soil tillage system (RP).
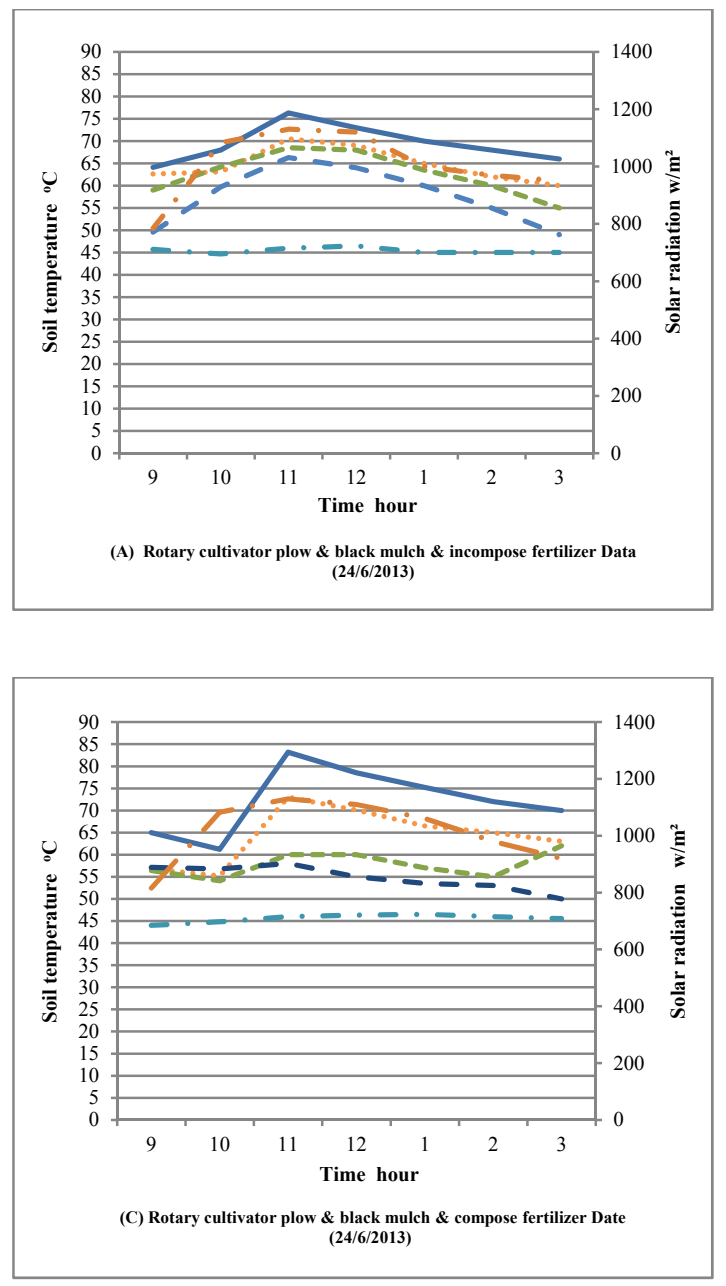
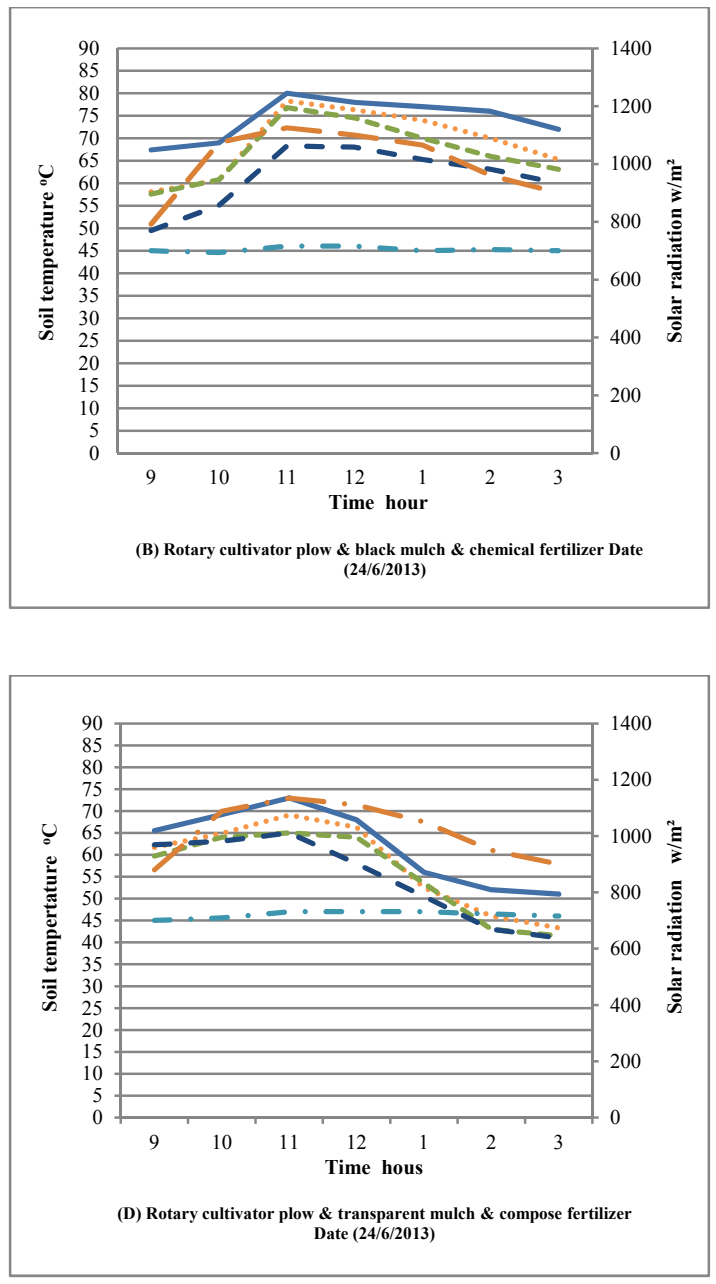

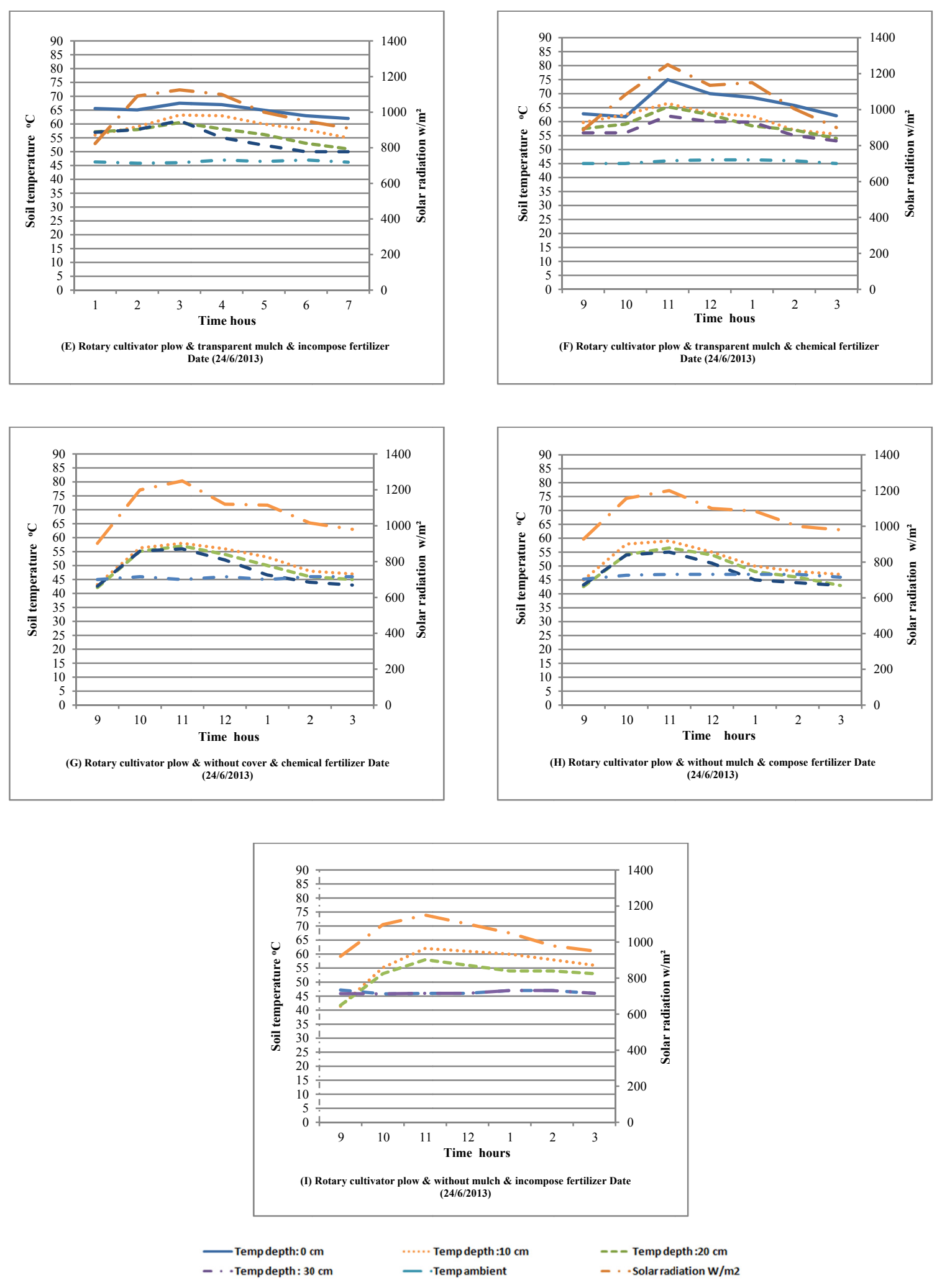

Figure 2. Relationship between soil temperature through soil depths, ambient, solar radiation in time using tillage system (RP), soil solarization system difference and fertilizer type 
Table 2. Means, coefficient of variation (CV), standard error of mean (SEM) for the diurnal average soil temperature at three depths using tillage system (MP) under effect soil solarziation systems and fertilizer types

\begin{tabular}{|c|c|c|c|c|c|c|c|}
\hline \multirow{2}{*}{ Treatment } & \multicolumn{7}{|c|}{ Time (hours) } \\
\hline & 9 & 10 & 11 & 12 & 1 & 2 & 3 \\
\hline \multicolumn{8}{|c|}{ * Means temperature $\left({ }^{\circ} C\right)$ at gap between mulch and soil surface } \\
\hline Soil transparent mulch \& incompose & 48 & 63.3 & 66.3 & 65.6 & 58.1 & 56.1 & 54 \\
\hline Soil transparent mulch \& compose & 47.5 & 67.7 & 68 & 60.1 & 45.8 & 43.1 & 43.1 \\
\hline Soil transparent mulch \& chemical fertilizers & 49 & 68.6 & 73 & 71 & 66.7 & 64.3 & 63 \\
\hline Soil black mulch \& incompose & 47.2 & 60.8 & 67 & 64 & 54.8 & 52 & 50 \\
\hline Soil black mulch \& compose fertilizers & 62.5 & 69.4 & 72 & 70 & 66.3 & 65 & 64 \\
\hline Soil black mulch \& chemical & 67.9 & 76.6 & 81 & 78 & 70.7 & 68 & 65 \\
\hline SEM & 3.7 & 2.2 & 2.2 & 2.5 & 3.7 & 3.8 & 3.6 \\
\hline CV (\%) & 16.9 & 8.0 & 7.7 & 9.2 & 15.3 & 16.3 & 15.8 \\
\hline \multicolumn{8}{|l|}{ ** Means soil temperature $\left({ }^{\circ} \mathrm{C}\right)$ at $10 \mathrm{~cm}$ depth } \\
\hline Soil transparent mulch \& incompose & 50.5 & 52.3 & 51 & 50 & 50 & 46 & 44 \\
\hline Soil transparent mulch \& compose & 47.3 & 62.7 & 66 & 63.1 & 42.3 & 41.2 & 40.1 \\
\hline Soil transparent mulch \& chemical fertilizers & 47.4 & 62.1 & 70 & 68 & 41.3 & 40.1 & 40 \\
\hline Soil black mulch \& incompose & 47.7 & 58.3 & 61 & 58 & 51.1 & 48.1 & 48 \\
\hline Soil black mulch \& chemical & 60.1 & 63.6 & 65 & 63.2 & 55.1 & 54 & 55 \\
\hline Soil black mulch \& compose fertilizers & 58 & 65 & 70 & 68 & 53.4 & 50.2 & 50 \\
\hline Soil without mulch \& incompose & 52 & 49.3 & 51 & 48 & 48 & 45.3 & 44 \\
\hline Soil without mulch \& compose & 50.5 & 47 & 52 & 50 & 48 & 45.3 & 45 \\
\hline Soil without mulch \& chemical fertilizers & 50.5 & 51 & 55 & 50 & 49.3 & 47 & 46.8 \\
\hline SEM & 1.5 & 2.3 & 2.6 & 2.7 & 1.5 & 1.4 & 1.5 \\
\hline CV $(\%)$ & 8.8 & 12.2 & 13.3 & 14.3 & 9.3 & 9.1 & 10.3 \\
\hline \multicolumn{8}{|l|}{ *** Means soil temperature $(\rho \mathrm{C})$ at $20 \mathrm{~cm}$ depth } \\
\hline Soil transparent mulch \& incompose & 47.3 & 50.6 & 52.1 & 50 & 48 & 46 & 42 \\
\hline Soil transparent mulch \& compose & 47.5 & 61 & 66 & 61 & 40.2 & 39.1 & 38.1 \\
\hline Soil transparent mulch \& chemical fertilizers & 49.2 & 60.2 & 65 & 62.1 & 39 & 38 & 39 \\
\hline Soil black mulch \& incompose & 49.5 & 59 & 60.1 & 56.3 & 50.1 & 47 & 46 \\
\hline Soil black mulch \& compose & 57.2 & 62.6 & 68 & 66.5 & 48.6 & 48 & 46 \\
\hline Soil black mulch \& chemical fertilizers & 60.4 & 62 & 66 & 65 & 61 & 60 & 58 \\
\hline Soil without mulch \& incompose & 50.5 & 47 & 52 & 50 & 48 & 45.3 & 45 \\
\hline Soil without mulch \& compose & 52 & 49.3 & 51 & 48 & 48 & 45.3 & 44 \\
\hline Soil without mulch \& chemical fertilizers & 50.5 & 51 & 55 & 50 & 49.3 & 47 & 46.8 \\
\hline SEM & 1.4 & 2.0 & 2.3 & 2.4 & 2.0 & 2.0 & 1.9 \\
\hline CV $(\%)$ & 8.5 & 11.1 & 11.7 & 12.8 & 13.1 & 13.5 & 12.8 \\
\hline \multicolumn{8}{|l|}{ **** Means soil temperature $\left({ }^{0} \mathrm{C}\right)$ at $30 \mathrm{~cm}$ depth } \\
\hline Soil transparent mulch \& incompose & 39 & 50.5 & 53.8 & 50.2 & 40.2 & 40.1 & 42.1 \\
\hline Soil transparent mulch \& compose & 49.6 & 62.7 & 65.5 & 53.1 & 38.5 & 42.1 & 37.1 \\
\hline Soil transparent mulch \& chemical fertilizers & 49.4 & 57.7 & 60.7 & 56.3 & 35.8 & 36.5 & 36 \\
\hline Soil black mulch \& incompose & 52.5 & 56.8 & 62 & 56 & 47 & 47 & 45 \\
\hline Soil black mulch \& compose & 64.4 & 52.8 & 62 & 62 & 49.2 & 48.1 & 45 \\
\hline Soil black mulch \& chemical fertilizers & 65.8 & 57.7 & 68.6 & 65 & 57.5 & 55 & 53 \\
\hline Soil without mulch \& incompose & 43.1 & 46.4 & 49 & 45 & 44.3 & 43.8 & 43.1 \\
\hline Soil without mulch \& compose & 50 & 48.1 & 55 & 53.1 & 50.1 & 45.3 & 44 \\
\hline Soil without mulch \& chemical fertilizers & 48.3 & 50.1 & 56 & 50 & 48.1 & 45.1 & 44.5 \\
\hline SEM & 2.9 & 1.7 & 2.0 & 2.0 & 2.2 & 1.7 & 1.6 \\
\hline CV $(\%)$ & 17.1 & 10.0 & 10.4 & 11.3 & 14.7 & 11.6 & 11.3 \\
\hline
\end{tabular}

Note. ${ }^{*}$ Means temperature $\left({ }^{\circ} \mathrm{C}\right)$ at gap between mulch and soil surface, ${ }^{* *}$ Means soil temperature $\left({ }^{\circ} \mathrm{C}\right)$ at $10 \mathrm{~cm}$ depth, ${ }^{* * *}$ Means soil temperature $\left({ }^{\circ} \mathrm{C}\right)$ at $20 \mathrm{~cm}$ depth, $* * * *$ Means soil temperature $\left({ }^{\circ} \mathrm{C}\right)$ at $\left.30 \mathrm{~cm} \mathrm{depth}\right)$. 
Table 3. Means, Coefficient of Variation (CV) standard error of mean (SEM) for the diurnal average soil temperature at three depths used tillage system (RP) under effect soil solarziation systems and fertilizer types

\begin{tabular}{|c|c|c|c|c|c|c|c|}
\hline \multirow{2}{*}{ Treatment } & \multicolumn{7}{|c|}{ Time (hours) } \\
\hline & 9 & 10 & 11 & 12 & 1 & 2 & 3 \\
\hline \multicolumn{8}{|c|}{ * Means temperature $\left({ }^{\circ} C\right)$ at gap between mulch and soil surface } \\
\hline Soil black mulch \& incompose & 64.1 & 68 & 76.3 & 73 & 70 & 68 & 66 \\
\hline Soil black mulch \& chemical fertilizer & 67.4 & 69 & 80 & 78 & 77 & 76 & 72 \\
\hline Soil black mulch \& compose fertilizers & 65 & 61.2 & 83.2 & 78.5 & 75.2 & 72 & 70 \\
\hline Soil transparent mulch \& compose & 65.5 & 69.2 & 73 & 68 & 56 & 52 & 51 \\
\hline Soil transparent mulch \& incompose & 65.6 & 65.1 & 67.5 & 67 & 65 & 63 & 62 \\
\hline Soil transparent mulch \& chemical fertilizers & 62.8 & 61.7 & 75 & 70 & 68.6 & 65.8 & 62.1 \\
\hline SEM & 0.6 & 1.4 & 2.2 & 2.0 & 3.0 & 3.3 & 3.0 \\
\hline CV $(\%)$ & 2.3 & 5.4 & 7.2 & 6.8 & 11.0 & 12.5 & 11.7 \\
\hline \multicolumn{8}{|l|}{$* *$ Means soil temperature $\left({ }^{C} \mathrm{C}\right)$ at $10 \mathrm{~cm}$ depth } \\
\hline Soil black mulch \& incompose & 62.6 & 63.1 & 70.5 & 69 & 65 & 62 & 60 \\
\hline Soil black mulch \& chemical fertilizer & 58.1 & 60.7 & 78.3 & 76.3 & 74 & 70 & 65.3 \\
\hline Soil black mulch \& compose fertilizers & 56.8 & 55.2 & 73 & 70.1 & 66.5 & 65 & 63 \\
\hline Soil transparent mulch \& compose & 61.7 & 64.9 & 69.1 & 66.3 & 52.5 & 46 & 43.3 \\
\hline Soil transparent mulch \& incompose & 56 & 59 & 63.2 & 63 & 60 & 58 & 55 \\
\hline Soil transparent mulch \& chemical fertilizers & 59.7 & 62.5 & 66.5 & 63 & 62 & 57 & 55.5 \\
\hline Soil without mulch \& chemical fertilizer & 43.2 & 56.3 & 58 & 56 & 53 & 48 & 47 \\
\hline Soil without mulch \& compose & 45 & 57.9 & 59 & 55 & 50 & 48 & 47 \\
\hline Soil without mulch \& incompose fertilizers & 41.4 & 55.2 & 62 & 61 & 60 & 58 & 56 \\
\hline SEM & 2.7 & 1.1 & 2.2 & 2.2 & 2.5 & 2.7 & 2.5 \\
\hline CV $(\%)$ & 15.4 & 6.0 & 10.1 & 10.6 & 12.7 & 14.4 & 13.8 \\
\hline \multicolumn{8}{|l|}{$* * *$ Means soil temperature $\left({ }^{\rho} \mathrm{C}\right)$ at $20 \mathrm{~cm}$ depth } \\
\hline Soil black mulch \& incompose & 59 & 64.2 & 68.5 & 68 & 63.5 & 60 & 55 \\
\hline Soil black mulch \& chemical fertilizer & 57.6 & 60.8 & 76.8 & 74.5 & 70 & 66 & 63.1 \\
\hline Soil black mulch \& compose fertilizers & 56.4 & 54.1 & 60 & 60 & 57 & 55 & 62 \\
\hline Soil transparent mulch \& compose & 59.7 & 64 & 65 & 64 & 53.5 & 43 & 41.5 \\
\hline Soil transparent mulch \& incompose & 57.2 & 58 & 60.5 & 58.2 & 56.2 & 53 & 51 \\
\hline Soil transparent mulch \& chemical fertilizers & 57.5 & 59.1 & 65.3 & 62.5 & 58.5 & 57 & 54 \\
\hline Soil without mulch \& incompose & 42.1 & 55.1 & 57 & 54 & 50 & 46 & 45 \\
\hline Soil without mulch \& compose & 42.6 & 54.1 & 56.5 & 54 & 48 & 46 & 43 \\
\hline Soil without mulch \& chemical fertilizers & 41.7 & 53 & 58 & 56 & 54 & 54 & 53 \\
\hline SEM & 2.6 & 1.4 & 2.1 & 2.2 & 2.2 & 2.4 & 2.5 \\
\hline CV (\%) & 15.0 & 7.3 & 10.4 & 11.1 & 11.9 & 13.8 & 14.8 \\
\hline \multicolumn{8}{|l|}{$* * * *$ Means soil temperature $(\rho \mathrm{C})$ at $30 \mathrm{~cm}$ depth } \\
\hline Soil black mulch \& incompose & 49.6 & 59.7 & 66.3 & 64 & 60 & 55 & 49 \\
\hline Soil black mulch \& chemical fertilizer & 49.5 & 55.1 & 68.3 & 68 & 65.3 & 63.1 & 60 \\
\hline Soil black mulch \& compose fertilizers & 57.1 & 56.8 & 58 & 55 & 53.5 & 53 & 50 \\
\hline Soil transparent mulch \& compose & 62.3 & 63.1 & 65 & 58 & 50.5 & 43 & 41 \\
\hline Soil transparent mulch \& incompose & 57 & 58 & 61.2 & 55.1 & 52.3 & 50 & 50 \\
\hline Soil transparent mulch \& chemical fertilizers & 56 & 56 & 62 & 60 & 59.8 & 55 & 53.1 \\
\hline Soil without mulch \& incompose & 42.6 & 55.2 & 56 & 52 & 46.6 & 44 & 43 \\
\hline Soil without mulch \& compose & 43.2 & 54 & 55 & 51 & 45 & 44 & 43 \\
\hline Soil without mulch \& chemical fertilizers & 47.2 & 45.8 & 46 & 46 & 47 & 47 & 46 \\
\hline SEM & 2.2 & 1.5 & 2.2 & 2.2 & 2.3 & 2.2 & 1.9 \\
\hline CV (\%) & 13.2 & 8.4 & 11.5 & 11.9 & 13.1 & 13.2 & 12.2 \\
\hline
\end{tabular}

Note. $*$ Means temperature at gap between mulch and soil surface, ${ }^{* *}$ Means soil temperature $\left({ }^{\circ} \mathrm{C}\right)$ at $10 \mathrm{~cm}$ depth, ${ }^{* * *}$ Means soil temperature $\left({ }^{\circ} \mathrm{C}\right)$ at $20 \mathrm{~cm}$ depth, $* * * *$ Means soil temperature $\left({ }^{\circ} \mathrm{C}\right)$ at $30 \mathrm{~cm}$ depth. 


\section{Conclusions}

The results obtained from the experiment lead to the following conclusions:

$>$ The results showed that different mulching systems have varying effects on soil temperature.

> The higher soil temperature was obtained with soil black mulching under influence the soil tillage systems and fertilizer types different compared with the soil transparent mulch and without mulch.

$>$ Tillage system (RP) was recorded highest mean of soil temperature compared with tillage system (MP) under difference soil depths and fertilizer types.

$>$ Noticed that the diurnal variation of surface temperature is decreasing as the depth of the soil increases.

$>$ The diurnal variation of soil temperature is influenced by soil depth, moisture content and incoming solar radiation.

\section{References}

Angima, S. (2009). Season extensions using mulches (Vol. IV, No 3). Oregon State University.

Aniekwe, N. L., Okereke, O. U., \& Anikwe, M. A. N. (2004). Modulating effect of black plastic mulch on the environment, growth and yield of cassava in a derived savannah belt of Nigeria. Tropicultura, 22, 185-190

Anikwe, M. A. N., Mbah, C. N., Ezeaku, P. I., \& Onyia, V. N. (2007). Tillage and plastic mulch effects on soil properties and growth and yield of cocoyam (Colocasia esculenta) on an uitisol in southeasterm Nigeria. Soil \& Tillage Research, 93, 264-272. http://dx.doi.org/10.1016/j.still.2006.04.007

Avissar, R., Mahrer, Y., Margulies, L., \& Katan, J. (1986). Field Aging of Transparent Polyethylene Mulches: I. Photometric Properties. Soil Science Society of America Journal, 50(1), 202-205. http://dx.doi.org/10.2136/sssaj1986.03615995005000010038x

Bachmann, J. (1997). Thermisches verhalten der Böden. In H. P. Blume, F. Henningsen, W. R. Fisher, H. G. Frede, R. Horn, \& K. Stahr (Eds.), Handbuch der Bodenkunde (2 ed., pp. 1-40). Landsberg/Lech.

Cambell, G. S. (1985). Soil physics with basic - Transport models for soil-plant systems. Elsevier, Amsterdam.

De Vries, D. A. (1996). Thermal Properties of Soil. In W. R. Van Wijk (Ed.), Physics of Plant Environment (Vol. 3, pp. 210-235). North-Holland Publishing Company, Amsterdam.

Fabrizzi, K. P., Garcia, F. O., Costa, J. L., \& Picone, L. I. (2005). Soil water dynamics, physical properties and corn and wheat responses to minimum and no-tillage systems in the southern Pampas of Argentina. Soil Till. Res., 81(1), 57-69. http://dx.doi.org/10.1016/j.still.2004.05.001

Hillel, D. (1998). Environmental Soil Physics (p. 771). Academic Press, London.

Hu, W., Duan, S., \& Sui, Q. (1995). High yield technology for ground nut. Int. Arachis Newsletter, 15(Suppl.), $1-22$.

Johnson, M. D., \& Lowery, B. (1985). Effect of three conservation tillage practices on soil temperature and

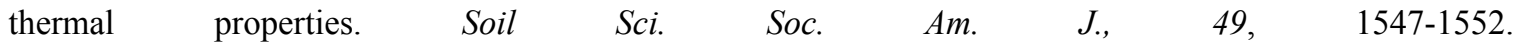
http://dx.doi.org/10.2136/sssaj1985.03615995004900060043x

Kowalik, S. (2004). Zagadnienie z gleboznawstwa dla studentów inzynierii środowiska (p. 120). Uczelniane wydawnictwa naukowo-dydaktyczne, Kraków.

Lamont, W. J. (1999). The use of different control mulches for yield and earliness. Procedings of the New England vegetable and berry growers conference and trade show, Strubridge, Mass (pp. 299-302).

Liakaatas, A., Clark, J. A., \& Monteith, J. L. (1986). Measurement of the heat balance under plastic mulches. Agricultural and Forest Meteorology, Amesterdam, 36, 227-239. http://dx.doi.org/10.1016/0168-1923(86)90037-7

Olasantan, F. O. (1999). Effect of time of mulching on soil temperature and moisture regime and emergence, growth and yield of white yam in western Nigeria. Soil Till. Res., 50(3-4), 215-221. http://dx.doi.org/10.1016/S0167-1987(98)00192-5

Park, K. Y., Kim, S. D., Lee, S. H., Kim, H. S., \& Hong, E. H. (1996). Differences in dry matter accumulation and leaf area in summer soyabeans as affected by polythene film mulching. RDA J. Agric. Sci., 38, 173-179.

Ramakrishna, A., Tam, H. M., Wani, S. P., \& Long, T. D. (2006). Effect of mulch on soil temperature, moisture, weed infestation and yield of groundnut in northern Vietnam. Field Crops Res., 95(2-3), 115-125. 
http://dx.doi.org/10.1016/j.fcr.2005.01.030

Sarkar, S., Paramanick, M., \& Goswami, S. B. (2007). Soil temperature, water use andyield of yellow sarson (Brassica napus L. var. glauca) in relation to tillage intensity and mulch management under rainfed lowland ecosystem in eastern India. Soil Till. Res., 93, 94-101. http://dx.doi.org/10.1016/j.still.2006.03.015

Schales, F. D., \& Sheldrake, R. (1963). Mulch effects on soil conditions and tomato plant response. Proc. 4th Natl. Agr. Plastics Conf. (pp. 78-90).

Scharringa, M. (1976). On the representativeness of soil temperature measurements. Agric. Meteorol., 16, 263-276. http://dx.doi.org/10.1016/0002-1571(76)90046-7

Streck, N. A., Schneider, F. M., \& Buriol, G. A. (1994). Effect of soil solarization on thermal regime of plastic greenhouse soil. Cienc. Rural, 24(2). http://dx.doi.org/10.1590/S0103-84781994000200001

\section{Copyrights}

Copyright for this article is retained by the author(s), with first publication rights granted to the journal.

This is an open-access article distributed under the terms and conditions of the Creative Commons Attribution license (http://creativecommons.org/licenses/by/3.0/). 